\title{
Aspects of British University Librarianship, 1877-1977
}

\begin{abstract}
This review of developments in British university libraries is divided into three major periods, 1877-1919, 1920-1945, and 1946-1977. Major subjects covered include library services, staffing, management attitudes, buildings, and automation. The role of the University Grants Committee in library development is stressed, and present economic difficulties and problems arising from the recent Atkinson Report are discussed.
\end{abstract}

$\mathrm{T}$ he British Library Association was founded in 1877. The intervening century of its existence has been devoted to intensifying and broadening the professionalization of librarianship. For the first fifty years of the century, university librarians and their staffs remained apart from this movement. This disinterest was of little moment. Universities were few in number and small in size, their libraries inconsiderable, and university librarians with what might be taken to be professional aspirations rare.

It was not until 1928 that university librarians and their interests were brought formally within the professional fold with the establishment of the University and Research Section of the Library Association. Two years later the section had recruited a total membership of 85 . The slow but steady growth in membership during the interwar years was a prelude to the substantial increases of the postwar period. The section had 428 members in 1946;

Norman Roberts is senior lecturer, Postgraduate School of Librarianship and Information Science, University of Sheffield, Sheffield, England.
1,100 in $1950 ; 1,850$ in $1960 ; 3,388$ in 1970; and 3,989 in 1976. ${ }^{1}$

The magnitude of these figures reflects something of the educational revolution (in British terms!) that overtook the university sector during the postwar years. In reacting to social, political, educational, and economic factors of national significance during this modern period, universities developed their libraries to unprecedented levels of provision and services. We now know that these factors are not always expansive in their effects but that, either way, they cannot be ignored. It is enforced responsiveness to the restrictive aspects of these forces that is compelling university librarians currently to adopt more limited aims and aspirations.

To describe in detail the development of university libraries to this latest point would be to engage in a lengthy, involved, and particularist story. Both space and interest dictate a simplification and a high level of generalization. To this end, the history of a century is condensed into three periods: 1877-1919, 1920-1945, and 1946 to date.

The simplifications associated with this procedure may be misleading because they hint at a greater degree of system and planning than should ever be at- 
tributed to the British approach to higher education. Much of what is said may be applied to Scottish libraries, but the generalizations are based, in the main, on university libraries in England and Wales. This qualification is necessary because higher education has been managed more sensibly in Scotland.

For an American audience it may be necessary to point out that this review excludes the treatment of polytechnics, colleges of education, and institutes of higher education, which also contribute to tertiary education. The history of each institution is so different from the others and from universities that no single piece of any point and substance could be written about the group.

$$
\text { 1877-1919 }
$$

By the turn of the nineteenth century the monopoly of university education held by Oxford and Cambridge had been breached. The University of London had been established in 1836; the ecclesiastical foundation of the University of Durham had received its charter in 1837 to be followed by a clutch of colleges that became known as civic universities. ${ }^{2}$ These colleges, unlike Oxford and Cambridge, had their origins in institutions that emphasized scientific, technical, and medical instruction.

Their establishment and subsequent elevation to university status owed everything to civic pride and local initiative and nothing to the idea of a national system of higher education planned by the central government. ${ }^{3}$ The results were distinct and individual universities and, as a consequence, distinct and individual libraries.

The optimism that brought the civic universities into being proved insufficient to maintain them in a state of solvency. In 1889, following a precedent established to favor the Welsh colleges, central treasury funds were distributed for their support. The initial sums were small, but the decision was of enormous importance. The practice of providing central government funds to maintain and develop the university sector was continued and expanded and, in 1919, formalized through the establishment of the University Grants Committee (UGC).

The work of this curiously British body enabled British universities to meet the challenges of the twentieth century with increasing state support while resisting, with a remarkable degree of success for most of the period, encroachments by the state upon their autonomy. ${ }^{4}$ The task of the UGC was seen as combining "the proper autonomies of the universities with the proper attention to effective use of scarce national resources." 5 In performing these tasks the UGC came to exert such a dominant influence upon university libraries that their histories cannot usefully be separated.

However, this is to get ahead of the narrative. During this period central government support grants were occasional and small. Generally, universities, old and new, relied upon their own resources. In most instances, as a result, libraries fared badly. Universities were at first slow to realize either the necessity for a library or its necessary size and scope; most of them passed through the stages of a cupboard, a room which also served for other purposes, a room devoted to the library, and a series of rooms adapted with greater or less success.

In 1918 probably only two of themManchester and University College, London-could be said to be "adequate to the functions of a university library." 6 University libraries were characterized by small, indifferent collections organized on the closed-access principle. The post of librarian was rarely fulltime; the few full-time staff in the post were untrained. Accommodation for books, readers, and staff was usually inadequate and budgets trifling. 
The universities of the period were small: by 1913-14 the full-time university population numbered only 20,547 . This factor, coupled with the generally straitened financial circumstances and prevailing educational attitudes, did not generate an environment conducive to the development of libraries. Neither did it encourage the progress of professional librarianship.

\section{0-1945}

The end of World War I found British universities much debilitated. The University Grants Committee was established (1919) to assist in their recovery and to help universities meet the pent-up demand for university education. In 1920-21 the university fulltime population was 36,709 . At the outbreak of World War II, the academic year 1938-39, it had increased to 50,246 . The increase was accommodated in expanded universities and by the establishment of new university colleges (Leicester in 1918, Hull in 1928).

To understand the development of university libraries during this period it must be remembered that, even by 1938-39, only three English universities topped 5,000 full-time students (London, Oxford, and Cambridge). Only one other, Manchester, exceeded 2,000 . At the lower end of the scale the universities of Sheffield and Southampton mustered 767 and 268 full-time students respectively. The library staffs of British universities totaled 106 in 1920 21 and around 150 by the end of the period.

It was not surprising that the newly constituted University Grants Committee, which held that "the character and efficiency of a university may be gauged by its treatment of its central organthe library," found much to complain about and castigate in the state of university libraries in the decade following the end of World War I. In 1921 the committee regretted to "find that a num- ber of authorities are not yet in a position to make adequate provision whether for buying books or for paying the library staff."

The absence of the basic necessities was again stressed in 1923: "With few exceptions, and we understand that even the great libraries of Oxford and Cambridge were not among them, the libraries of our Universities and Colleges are suffering a process of starvation, and large additional sums of money will have to be spent upon them before they could be regarded as maintained on a scale commensurate with their real needs."

The adequate funding of libraries remained a cause for concern throughout the 1920s. In 1927 the UGC, trying to influence the priorities of universities and government alike, pointed out that university libraries presented an "essentially gloomy picture." In their report of that year it was asserted that "the total figure for all our grant-aided universities and colleges put together appeared to be little larger than the combined figure for the two universities of Harvard and Yale." ${ }^{9}$

As late as 1930 the UGC was still calling universities to task for neglecting their libraries: "We can still wish it were more common to find a clear conception of the aims and ideals of a University guiding and informing the practice of governing bodies. . . . Many university institutions have still to give evidence of being conscious that their quality and standing as instruments for the advance of learning may to a great extent be gauged by their libraries and the policy pursued for the maintenance and development of them."10 Despite a decade of endeavor following the end of the war, the views of the UGC regarding the role of the library in university education were far from being implemented.

By the middle of the 1930s, however, there were signs that these repeated 
goadings were having some effect. Staffing levels were improving, book funds were increased, and new libraries were provided to replace inadequate makeshifts and to cater for expansion. For example, Cambridge opened its new library in 1934, Southampton in 1935, Leeds in 1936, Swansea in 1937, Exeter in 1939.

As universities grew, their libraries came to appreciate the need for organized forms of cooperation to improve the availability of materials unavailable locally. In 1925 university librarians established their own scheme of interlibrary lending that, in 1931, was merged into the national system of interlending. The growing realization of interdependence resulted in the compilation and publication of the Union Catalogue of Periodical Publications in University and College Libraries in 1937. 11

During these years, university librarianship was establishing its professional credentials. The ideals of the time were clearly expressed in one of the few general texts on university libraries and librarianship by British authors. This work, Woledge and Page's Manual of University and College Library Practice, unknowingly was to be a memorial to the past, to forms of librarianship and associated educational attitudes that were to be transformed by social forces of unexpected power unleashed by World War II. This manual makes it clear, as has been noted, that university libraries had progressed during the previous decade but that much remained to be done.

For example, even in 1940, "there are only a few universities in the British Isles where the membership of the Senate includes the librarian. ... The real truth is that the universities have never quite made up their minds what the constitutional position of the librarian should be. Is he purely an academic person? Is he a member of the adminis- trative staff? In the confusion the librarians may fail to secure the dignity and privilege that belong to the one or the other."12

Privilege and dignity are not words that come easily to the lips of professional librarians these days, but the problem outlined was of the utmost importance to the librarians of the time. It emerges from Woledge and Page that librarians had succeeded only partially in convincing the academic establishment of the essential role of libraries and librarianship in the attainment of the educational goals of universities.

As far back as 1921, the UGC had expressed the view that the librarian should be "an officer of professional status and emoluments, and an ex-officio member of the Senate, with the right of attending meetings of all faculties." ${ }^{33}$ Despite such support, only five universities had accorded professional status to their librarians by 1940 and only in half of our universities "does one find that the librarian is a member of the Library Committee with the power to vote."14

What professional attitudes characterized this period? The overwhelming importance of collection building, with the emphasis firmly and positively on the needs of research, was an unchallenged article of faith. "It is not by the grandeur nor even by the beauty of its buildings and their furnishings that a university library will attract its readers, but solely by the richness of the collection within its walls,"15 and "it is not the practice in this country, nor is it advisable, to buy duplicate or multiple copies of books much in demand."16 "It may, however, safely be asserted that it is the aim of most university librarians to devote the minimum of expenditure to purchases which are only of interest to undergraduates in preparing for examinations, and to apply the great bulk of available funds to the acquisition of 
books and periodicals of a kind which assist research in as many fields as possible." ${ }^{17}$ The unknown future was to make a nonsense of such a view, but at what cost in terms of research and scholarship we may yet have to discover.

During this period the principle of direct access to as large a proportion of the stock as was practical became generally accepted. This end was accomplished through a variety of systems reflecting the diverse origins and histories of the universities and their libraries. Classification and cataloging practices differed widely. In Woledge and Page the "guard book" form of catalog was advocated, yet another example of the traditional influence of great institutions-in this case the British Museum Library. The author catalog was regarded as essential, but "the subject catalogue is less necessary; competent teachers and research workers know their subject and have access to their own bibliographies"18_a view held by many university librarians long after the circumstances that give it a degree of validity had vanished.

The libraries of the period were functionally organized and run, in the main, by staff without professional training other than that gained on the job. Their librarians strove for centralized control to bring order out of the chaos of departmental and sectional collections. Few services were offered beyond the lending of material and the provision of reference collections. The more progressive librarians were devoting some thought but, perhaps, rather less effort to instruction in the use of libraries.

Currently it is fashionable to criticize university librarians for their commitment to collection building and, by implication, their preoccupation with size. Such criticisms frequently ignore the research context within which university librarians placed their libraries and the fact that librarians were reflecting, as they were expected to do, a scale of priorities established by the universities. On this issue the Manual is unequivocal: "Nor are mere numbers of volumes of any greater significance in a university library than in one of any other sort. Not how many, but what books are in the library is the vital consideration. ... It is well always to remember that there is a world of difference between the functions of the library of a modern university and a national library, and that the university library has no justification for its existence save in so far as it aids the work of the university."19

The Manual describes the middle ages of British university librarianship-the nonscientific era. Nothing makes this clearer than the statement that in "no English university has any attempt been made to assess the real needs of the library in terms of pounds, shillings and pence, on the basis of a systematic examination of its existing book collections and their deficiencies." Embedded in the context of this particular text the view has a curiously modern ring to it. The succeeding phase of librarianship differed in many ways from that described in the Manual but in no way more than in the attempts to place librarianship on a systematic, scientific footing.

\section{6-1977}

In 1938-39, 50,246 full-time students attended British universities. Postwar demand for higher education had raised the total to more than 85,000 by 1950 51. Misreading the signs while still influenced by prewar educational and social attitudes, the UGC came to the conclusion that the demand for university education would level off. This seemed desirable because this body was also of the opinion, fairly generally held, that "no further substantial increase in student numbers could be expected in the immediate future without 
reducing university standards." 20 This view, so seriously propounded, was soon pushed aside as an irrelevance by egalitarian political and social forces and by insistent demographic pressures.

The 1950s simply reinforced what should have been perceived sooner by the representatives of the university system. The educational expectations of the British people had been transformed. An increasing proportion of the seventeen- to eighteen-year-old age group was staying longer at school and qualifying for university admission (this phenomenon came to be called "the trend"). In addition, during the 1960s, the universities were required to cope with the educational consequences of the "bulge," i.e., the increased postwar birthrate.

By all previous British standards the effect upon the university population was remarkable. During the decade $1950-51$ to $1960-61$, the full-time numbers enrolled at British universities rose to 107,699 ; by $1977-78$ the numbers are expected to be around 281,000. More than a five-fold increase over the 193839 figure, it remains a lower proportion of the comparable age groups attending universities than in the United States and most European countries. Of course, as a consequence, "wastage rates" are also considerably lower. Changes of this magnitude inevitably influence libraries. In retrospect, it is possible to see that the change in scale associated with more generous funding than hitherto brought to university libraries a brief golden age. This period barely lasted out the 1960s.

That university librarianship was moving into a period of change was evident by the growing expression of professional cohesion, the recognition that learned libraries had a common cause to further but no suitable agency or association to focus interest and advocacy.

Interestingly, university librarians did not feel that the Library Association offered a natural home for their proposed activities. In September 1950 the Standing Conference of National and University Libraries (SCONUL) was established, which would "firstly . . . provide opportunities for the discussion of matters of particular concern to large learned libraries by those responsible for their administration, rather as does the Association of Research Libraries in the USA. Secondly . . . could represent their views to outside bodies more accurately and with more weight than the Library Association can at present."21

Initially, SCONUL confined its membership to the larger libraries, but the size qualification was relaxed over the years. Now close to seventy institutions are in membership meetings twice a year to discuss technical and policy issues. The activities of SCONUL are varied. Much of its work is carried out through subcommittees; for example, there are subcommittees on cooperation in acquisitions, export of printed books and manuscripts, training for librarianship, new media, information services, etc. A number of influential conferences and "exchange of experience" seminars also have been organized. On occasions, when a general university library viewpoint has to be expressed, librarians look to SCONUL to take the lead.22

Although university librarians may have perceived the need for a collective professional approach to library problems, the immediate postwar development was slow. As ever, the UGC recognized that there was a need to improve library funding. The committee noted that between 1938-39 and 195152 , book funds had increased from $£ 87,802$ to $£ 321,269$. This seemed substantial enough in the context of past experience but insufficient to meet the prevailing, quite exceptional, circumstances of expansion. In their own words, "there are few, if any, universi- 
ties and colleges which are not suffering from a shortage of the books which are requisite for undergraduate reading." This emphasis on undergraduate reading was only a preliminary indication of what was to become a major shift in interest.

Nonetheless, the committee understood, perhaps better than the librarians of the time, what the generally canvassed solution to the problem would bring in its train.

There is room for great expansion and improvement, and it is a matter of regret that owing to the many pressing claims on the resources at our disposal so little has been possible to meet the almost universal need for better library accommodation. But whatever improvements in this respect the future may hold in store, there seems to be little prospect that it will ever be possible wholly to relieve the pressure on libraries by means of expansion, and in these circumstances it will probably always be necessary for libraries to be highly selective both in what they buy and in what they keep. We sometimes wonder whether, in dealing with books of the kinds needed mainly by undergraduates, the possibilities of "weeding" are sufficiently exploited. ${ }^{23}$

Expansion, then, was not limitless. It was not a doctrine to find favor with contemporary librarians intent upon making up for past deficiencies. No attempt was made to discover, even with such a hint from UGC, at what distance from their current positions lay the possible and desirable limits of expansion. It was an ignorance without penalties in times of relative plenty, but it left librarians vulnerable in a world of educational priorities adjusted to unprecedented economic harshness.

At last the message of change got through. The UGC recognized that "the major change which has come over the university scene since 1953 is the increased pressure on the universities to admit higher numbers of students."24 The influential Robbins Report reinforced the trend and secured its educational acceptance by insisting that opportunities should be provided for those who desired higher education. ${ }^{25}$ The eventual result was the enlargement of existing universities, the establishment of new universities, and the elevation of colleges of advanced technology to university status. (New universities were established at Sussex, York, East Anglia, Essex, Kent, Warwick, and Lancaster, following on the earlier Keele.) Such developments were associated with the initiation of large capital works for libraries. The consequent planning exercises brought the realization that little enough was known about the physical relationships between the functions of libraries and their architectural expressions. ${ }^{26}$

From this recognition of professional ignorance, made in 1958, and the subsequent steps taken to remedy the situation $^{27}$ may be dated the beginnings of a new, inquiring type of university librarianship that was to examine critically, and sometimes unsympathetically, the traditional practices and beliefs of university librarianship. The role of the UGC in pushing librarians along this path cannot be overrated.

In 1964 this committee pointed out that there was a "very great need for fundamental rethinking by the universities of their library policies." ${ }^{28}$ As part of their own effort to understand the nature of the library problem the committee formulated a number of seemingly obvious questions. One of these represented a recurring theme in UGC thinking and one that seemed to worry the distributors of central government funds more than it did librarians. It was: "Could any university reasonably expect now to be able to maintain a library or libraries to cover all the needs of its staff and students, particularly in the fields of research?" 
The answers provided by university librarians to such questions seemed less than convincing. The UGC determined on an attempt to find its own answers. This it did by setting up a committee of inquiry, the Committee of Library Problems in Institutions of Higher Education. ${ }^{29}$ In 1967 this body produced the Parry Report, so called after the chairman, Sir Thomas Parry, Principal of the University College of Wales. ${ }^{30}$

This report ranged widely and critically over such topics as cooperation, interlibrary loans, the acquisition of library materials, accommodation, services, techniques, administration, staffing, finance, and collections. Much of what was discussed and recommended should have come as no surprise to a professional librarian. That such obviousness needed repeating in the context of university librarianship was as significant a commentary on the state of university librarianship as the recommendations.

The report was a rather unforceful charter for the more generous treatment of libraries by universities. Like almost everyone else at this time with a public platform available, the Parry Committee emphasized the need to discover more about the use of university libraries and recommended the establishment of a permanent Libraries Sub-Committee of the UGC "in order to stimulate a continuing interest in the study of library problems." This recommendation was ignored. It was noteworthy that the Parry Committee attempted (perhaps not too successfully) to practice what it preached. It was the first report to make use of special data-gathering exercises.

Perhaps the most important contribution of the Parry Committee lay in its exposure of inadequate library funding. It was discovered that, on average, libraries were allocated 3.8 percent of current university expenditure. The figure needed increasing to 6 percent of total expenditure. Earlier librarians had asserted library expenditure cannot be fixed as a definite proportion of the total expenditure of the university, for this will be affected by factors which have no influence on the demand for library facilities and will not be affected by some factors which have such influence. The force of this view had not diminished. But experience had demonstrated, all too conclusively, that there was little likelihood of establishing an appropriate library standard derived from internal, individually negotiated, criteria. Despite obvious criticisms there was a value in being present with a comparatively generous target figure. This is what the Parry 6 percent proved to be. A measure of the general acceptance of this formula is to be found in the numerous library annual reports relating their institutional expenditures to the Parry formula.

Although the Parry Report had little direct impact, the following years of the 1960s were good years for university librarianship. All the indicators moved favorably. Staff establishments expanded handsomely, book budgets and collections grew at a considerably faster rate than hitherto, and new and extended library buildings verged on the commonplace. Library use became more intensive, and new service attitudes appeared. The basic drive was provided by the growing university population and by the general acceptance, despite UGC wariness, of the view that if a demand for books and periodicals existed then libraries should be built, staffed, and maintained to meet such demand. The interests of the undergraduate were assuming a dominant position.

(For an American audience, references to growth must be given a perspective! Currently five British universities are around the 10,000-or-above mark: Cambridge, Oxford, London, Manchester, and Leeds. The middlesized universities range from 6,000 to 
8,000 . Smaller universities may have as few as 2,500 students.)

Before proceeding with the chronological story, it may be useful to review briefly some of the achievements of the 1960 s and early 1970 s.

\section{SERVICES}

As British universities came to lay greater emphasis upon their teaching functions, so did their libraries mirror the change by widening the variety of services that they offered and by intensifying and improving certain services and facilities. The user orientation of the transformed colleges of advanced technology probably helped to alter the practices and attitudes of university libraries.

With the needs of undergraduates more firmly in mind, it became increasingly apparent that the traditional forms of initiation to libraries and facilities and to the systematic use of subject literatures were wanting in terms of intent, execution, and effect. As a consequence, and probably years later than was required, university librarians came to devote far more ingenuity and resources to the problems associated with library induction and use.

By today it may be asserted that all forms of modern aids devised by librarians have been deployed to combat ignorance of, and apathy toward, library potential. To what effect it has worked may be a moot point. However well executed, such exercises relate to techniques and circumstances contextually divorced from the academic interests, pressures, and rewards that provide the most important educational variable of all: motivation.

Librarians have long appreciated the weakness of their externality relative to students. A possible solution lies in including library/literature skills as integral components of first-degree courses. Librarians have continued to make such proposals despite the noted reluctance of British academics to allow time for anything other than their own subjects or their own courses. Persistent advocacy, growing literature problems, and a general acceptance of the university librarians' professionalism seem now to be having an effect, however. For example, at Sheffield University, proposals for introducing bibliographical skills as a formal requirement for the first-degree sociology program are now being considered. Certain masters' programs already have this requirement.

Such developments are not novel, but they do recognize that the university library is a teaching instrument which has to be used positively and actively for greatest benefit. British universities are only on the threshold of such developments.

Another aspect of positive librarianship was represented in 1969 by the experimental introduction of information officers, specifically so called, into university libraries. Such personnel came to be regarded as specialists providing "personal help, extensive if required, with reference queries of all kinds; retrospective searches, whether manual or computer aided; current awareness, whether manual or computer aided; translation services." 31

None of these responsibilities were new to university libraries, but the systematic, special-library, personalized approach was. Significantly, a number of information officers came to be associated with computerized information services. In the experiments that preceded the appointment of such specialists, ${ }^{32}$ there were indications that imaginative and intensive deployment of information-oriented personnel could influence the information habits and receptivity of client groups. Such developments achieved a degree of impact.

For example, a committee considering the library resources of the University of London concluded that a central information service "to be staffed by ex- 
perienced Information Officers and to have access to all computerized sources of information as well as the more traditional ones, and to the necessary computers" was needed. ${ }^{33}$

Practical results have not completely lived up to the initial promise. And for good reasons. Fully effective information services demand high professional staffing ratios. The financial support for such provision was not forthcoming. As a result, in many universities the ratio of information officers to population served was absurdly low. The close personal links and the extramural relations, which are the essence of creative information work, were established in only a very small fraction of the potential market. For the present it must be accepted that the benefits of the information officer concept have yet to be fully realized.

Heavier demands upon their materials persuaded many libraries to adopt short-loan collections ${ }^{34}$ and variable loan policies ${ }^{35}$ to quicken stock turnover and improve its availability. Increasingly, computerized circulation systems assisted by providing quicker and more accurate location data. Computerized systems also enabled a number of university libraries to embark on programs of personal assistance, in the form of literature searches and current awareness services, of a depth not previously attempted. The comparative high costs of such services dampened enthusiasm in some quarters. There seems little doubt that computerized services have established themselves and now await only better financial circumstances for more general use.

The proliferating varieties of "new media" during this period also influenced library attitudes. The proponents of the new materials argued their case on the unity of communication, that physical form should not be the main criterion governing the legitimacy of communication devices for library storage and use. The arguments were persuasive and logical, but, nonetheless, university librarians moved to embrace the nonconventional forms with less than whole-hearted enthusiasm.

But the University Grants Committee was already convinced that university libraries should take in the new media and recommended "that library budgets might require to be reconsidered in the light of the provision of non-book materials." ${ }^{36}$ This was not the most positive of statements, perhaps, but enough to indicate that the restriction of university library services to the traditional materials may be too limiting. Much of the force of the "new media" argument is derived from the educational purposiveness of libraries.

As one of the more persuasive proponents expressed it, "the new media may provide the opportunity for libraries of all kinds to demonstrate their major contribution to education which has all too frequently been overlooked and to abandon the subordinate position in education which they have often been obliged to occupy."37

\section{StafFing}

By the 1960s it was uncommon for university librarians not to be of professorial standing and members of the senate, the academic ruling body of the university. It was normal for the librarian, or a representative, to have a place on the various faculty boards to ensure (at least in theory) the close correlation of educational developments and library provision. As this period progressed, so did the insistence upon formally acquired professional qualifications grow. This change in attitude was exemplified in the unlikeliest of institutions. For example, a committee convened to consider the library resources of Cambridge University insisted on "effective training in librarianship" for graduate and nongraduate library assistants alike. ${ }^{38}$ 
The organization of staff and their responsibilities was hierarchic and functional. The typical chain of chief librarian, deputy, sublibrarians, assistant librarians, senior library assistants, and library assistants tended to be managed on the principle of benign paternalism. The rigidities of the functional form of organization were modified to some extent by the adoption of subject specialization. ${ }^{39}$ The organization of staff in many university libraries came to approximate this pattern. "Approximate" is a very necessary qualifier in this context. The range of duties and responsibilities undertaken by subject specialists varied in the extreme. Although this form of organization was widely accepted, criticism from the staff viewpoint was not absent ${ }^{40}$; neither was criticism on the ground of operational inefficiency. ${ }^{41}$

Subject specialization represented an attempt to make work more varied and interesting, with benefits both for staff and users. The essence of subject specialization was to be found in the opportunities that it created, to a far greater degree than was possible in a functionally organized library, for professional librarians to establish close working relations with their clientele. This thrust toward greater personal service was carried further by the information officer movement. With few exceptions, however, concepts of personal service remain comparatively undeveloped in British university libraries. An overwhelming proportion of professional effort is devoted to intermediate, technical activities away from the areas of service. ${ }^{42}$ This fact may explain why numerous professionals complain of underutilized skills.

The expansive phase of university librarianship was associated with improved staffing establishments. From the staff point of view, continuing expansion meant the possibility of promotion and professional development through internal and external mobility. As a consequence, few university libraries introduced, or even needed, organized programs of staff development other than forms of specific in-service training. Staff development was a matter of individual initiative in circumstances that favored its exercise.

Circumstances of recent years have changed. The restrictions of the 1970s have stopped the growth of university libraries. The result is considerably less staff movement, or mobility. There are fewer external promotion opportunities, fewer internal. It follows that librarians will have to depend, to a far greater degree than previously, upon their present libraries for continuing job satisfaction and professional development. This means, in turn, the adoption of participative forms of management and systematic schemes of staff development. ${ }^{43}$

The full acceptance of this view and its implications will mark an important point in university librarianship-the belated recognition that the traditional forms of university library management were sustained by special circumstances that allowed professional satisfaction and development largely to be ignored without serious organizational penalities. Unchanging staff establishments combined with unsatisfied expectations will produce staff and management frictions of a kind not previously experienced.

\section{Management Attitudes}

Arguably, the most significant development during this period, because of its pervasiveness, was the displacement of the scholar-librarian ideal by that of the manager-librarian. ${ }^{44}$ The dichotomy may not be as clear as is sometimes represented, but, nonetheless, the labels represent a real shift in interest. The emphasis of librarians has moved from collection building and conservation to the active exploitation 
and manipulation of resources for the majority of users. Optimum use of materials, services, and personnel requires, for its achievement, decisions based on rigorous and systematic data collection and continuous organizational selfanalysis. Hunch and intuition still may have a place in university library management, but they live uncomfortably in a world given over to operational effectiveness and cost-efficiency.

Examples of routine and specially funded forms of research to gather what may broadly be termed management information are too numerous to list. However, an arbitrary selection will reveal the distance traveled by librarianship from the 1940s. The user now dominates. Numerous special surveys have been undertaken to uncover the characteristics and habits of this familiar, if little understood, creature. ${ }^{45}$

The age of certainty has faded. This was nowhere better illustrated than in the PEBUL project, which asked the once needless question: "What is the value of a library to a university?" 46 External circumstances were shaping library preoccupations. Attempts were initiated to establish "criteria for selection for acquisition and discarding of monographs" ${ }^{\prime 27}$ and to investigate problems associated with the relegation of less used holdings. ${ }^{48}$ The wider management view of libraries as systems was reflected in research activity at Lancaster University. ${ }^{49}$ In many ways the activities of this latter university seem to typify the new approach to library management.

A sustained interest in academic library management characterized the Cambridge Library Management Unit established in 1969. The unit (now at Loughborough University) carried out large-scale investigations into management and administration, developing, for these purposes, a range of techniques that have been used by many librarians throughout the world. The work of this unit was distinctive in that it placed emphasis upon the development of techniques that could be applied by library staffs themselves.

The Library Management Unit and much of the research undertaken by universities into management, computerization, information officers, stock management, etc., are financed by the British Library Research and Development Department (BLRDD). ${ }^{50}$ While the work of central government agencies is rarely free from criticism, it cannot be denied that this department has gained credit for the imaginative way in which it has distributed its awards and encouraged research in the university sector.

SCONUL, although it commands few resources, has also contributed to what is, in effect, a managerial revolution by providing a forum (formal and informal) for the discussion and transfer of ideas.

Another aspect of management responsiveness to changing circumstances may be found in a greater enthusiasm to undertake the responsibilities of cooperation both with other university libraries and with libraries of different types.

For example, the Sheffield Libraries Coordinating Committee brings together the public, polytechnic, and university libraries of the area. ${ }^{51}$ The South West Academic Libraries Cooperative Automation Project has brought together the university libraries of Bristol, Exeter, and Cardiff in a project that has produced a shared on-line circulation system and that is now developing shared cataloging facilities. The Birmingham Libraries Cooperative Mechanisation Project was pioneered jointly by public, polytechnic, and university libraries of the area. The exclusivity of British university libraries is not what it once was $!^{52}$

BuIldings

As late as 1957 "there seemed reason 
to express considerable doubts about the adequacy of British university library buildings." ${ }^{3}$ Most of the buildings were more than thirty years old. The establishment of new, and the expansion of existing, universities ushered in a period of widespread library building and an intensive interest in library planning.

This latter aspect was exemplified by the influential course on academic library planning held at York University in 1966 and organized by the Buildings Sub-Committee of SCONUL. This particular course also made evident the strong influence the United States has exerted (with suitable time lags) on librarianship in Britain. The main contributors at York were "two internationally famed academic library consultants," K. D. Metcalf and R. E. Ellsworth. ${ }^{54}$

The first of the postwar libraries was opened at Sheffield University in 1959. The library was planned not to be found wanting, as were so many libraries of the past, in storage capacity. It was unusual to find library planners taking such a determined view of the future, but the resultant building proved inflexible in the face of the new demands of the 1960s.

Greater experience of rapid change and the acceptance of open and modular planning ensured later buildings of improved flexibility and architectural distinction. In the view of one severe critic, "Of all the buildings of the last twenty years, excluding Sheffield which effectively represented a passing era, the only complete disaster seems to have been Exeter." 55 Of the most recent construction, the libraries of the universities of Nottingham (1973) and Leicester (1974) have achieved, within quite different physical and financial constraints, professional (architectural and library) acclaim.

Even in their physical construction, libraries were reflecting the fundamental nature of the educational changes which were occurring. An aspec of the University of Sussex Library was described in the following way: "This arrangement recognizes the prioritiesit is a reader's library rather than a librarian's library." Such a statement may be thought unexceptional, but it continued: "Work rooms and store rooms are reduced to bare essentials-it is the students who count." 56 The importance of the undergraduate to the university had become, by this time, an article of faith for librarians.

\section{Automation}

Southampton University Library "developed the first computerised circulation system (off-line) in this country." The year was 1966. Many university libraries have followed this lead and employed the computer to assist in a variety of housekeeping tasks, such as circulation, periodicals control, cataloging, acquisitions, indexing, etc., and for providing computer-based services, such as literature searching, current awareness, etc.

In this latter respect the experience of the University of London, which concluded a recent conference with the view that "there is a need for computer information services" and that "on-line services will form the central core of information service in the University," is probably indicative of the forthcoming trend. ${ }^{58}$ Application has been of a somewhat piecemeal nature, but it is now evident that the computer in academic libraries has passed through the experimental phase. It has established a place in the array of tools employed by librarians in their continuing search for greater efficiency and effectiveness. Most of the developments, many financed by the BLRDD, are recorded and reviewed in an excellent periodical publication entitled Vine. ${ }^{59}$

During the late 1960s the staffs of university libraries were acquiring and improving their computer expertise. 
These skills, together with subsequent technological progress, have brought university libraries closer to the threshold of integrated computerized systems. The obstacle to further advance is not lack of skill or technical capability; it is simply cost.

\section{Conclusions}

By the early 1970s the annual reports of university librarians were making repeated references to the adverse effects of inflation. As early as September 1970, SCONUL was predicting "a serious breakdown in the work and services of many university libraries unless their needs are more adequately safeguarded."60 Nothing as dramatic as a breakdown has yet occurred despite severe financial cuts imposed by the central government during the session 1974-75 and an inflation rate of a level and persistence scarcely contemplated in 1970.

But, breakdown or no, it was clear that university librarianship of the 1970 s was a quite different game. The era of expansion and matching budgets and library philosophies to suit had gone. It was replaced by a period of nogrowth and of rigorous financial constraints. The signs of the times were to be seen in frantic exercises undertaken to reduce, substantially, the number of periodical subscriptions; the growing reliance on interlending for the satisfaction of local demand; ${ }^{61}$ the freezing of posts; the smaller proportion of foreign and specialist material acquired; and in conferences $^{62}$ and institutional policies devoted to the business of extracting more from less.

Problems were not confined to current expenditure. Capital expenditure presented even more difficulties for the central agencies concerned with the distribution of resources. "At the end of 1974 the University Grants Committee had come to the conclusion that they were not going to have enough re- sources, either in the short term or the long term, to build new libraries at all universities on the scale needed to match an indefinitely growing number of books. Even if this had been possible it was doubtful whether it would have been the most sensible course to follow."63

The scale of the problem was all too evident: "So far as resources are concerned the moratorium imposed in the autumn of 1973 on UGC capital projects combined with reductions subsequently announced meant that the revised allocation of $£ 11.5 \mathrm{~m}$ (at 1973) for all purposes for 1974-75 had to be matched against $£ 52.8 \mathrm{~m}$ of outstanding projects." As we have noted, this concern of the UGC with the problem of the growth of libraries was not new. This time there was no doubt that librarians were to share fully in their concern. The result was the setting up of a working party headed by Professor Richard Atkinson, with terms of reference so tightly drawn that the conclusions and recommendations were almost foregone.

The main recommendation was that "the assessment of future university library building requirements on site should be based on the concept of a self-renewing library, that is, a library of limited size in which beyond a certain point material should be reduced at a rate approaching the rate of acquisition." These libraries should be supported by local stores with a capacity for roughly five years intake, and, as these stores filled up, the less used stock should be transferred to the British Library Lending Division. The water tank analogy may be appropriate here. As water is poured into the top tank (university library) a tap is regulated at the bottom of the tank to allow water out at the same rate of inflow. The outflow is poured into another tank (local store), which also has a controlled outflow into yet another tank (BLLD). ${ }^{64}$ 
Not much thought was given to the capacity and other problems of this latter tank.

The publication of the report was clumsily handled. It took some time for the academic world to realize that the UGC had, almost casually, undermined the main assumptions of British academic librarianship. The main grounds of criticism seem to be (1) the unresearched and subjective nature of the report; (2) the willful disregard of the problems of humanistic research; (3) the naive and misleading cost comparisons; (4) the assumption that British university libraries were operating at, or near, an optimum size level that made stabilization desirable; (5) qualitative aspects completely ignored; (6) centralization of decisions regarding the acquisition of substantial research collections; and (7) in making its recommendations, the UGC was taking educational decisions to which the universities, in the persons of their teaching staffs, were not party.

Arguments favoring the proposals tended to stress the need to face up to economic realities and to acknowledge the primary teaching functions of universities. As has been noted, university librarians were not unaware of economic realities or the shifting emphasis toward teaching. University libraries were responding to such pressures. Unfortunately, university librarians had failed either to establish, or to convey to the world at large, the nature of the relationship between quality of scholarship, research, and education and the quality of library collections and services. The lack of both qualitative and quantitative expressions of these relationships left them and their libraries peculiarly vulnerable to the financial onslaught of economically minded administrators.

For a variety of reasons this vulnerability was not previously tested during the 1960s. The political and educational attitudes of the 1970s have ensured that this vulnerability will be exploited to the fullest. It is to be hoped that university librarians will develop a philosophy of librarianship capable of adapting to difficult new circumstances and capable of restraining the extreme forms of administrative philistinism that emerge during such periods.

\section{REFERENCES}

1. These figures were provided by L. J. Taylor, Librarian, The British Library (Library Association Library).

2. Colleges were established in Manchester (1851), Leeds (1874), Bristol (1876), Nottingham (1877), Birmingham (1880), Liverpool (1882), Reading (1892), Sheffield (1897), Exeter (1901), Southampton (1902), the University of Wales (1893). For an excellent, succinct account of British universities see W. H. G. Armytage, "The Universities of Britain," in Commonwealth Universities Yearbook, 1976 (London: Association of Commonwealth Universities, 1976), p.180-97.

3. A. Briggs, "Development in Higher Education in the United Kingdom: Nineteenth and Twentieth Centuries," in W. R. Niblett, ed. Higher Education: Demand and Response (London: Tavistock Publications, 1969), p.95-116.
4. The UGC was "established by the issue of a Treasure Minute in July, 1919." "It is not a statutory body, and there is no legislation governing its existence." It might have been expected that such a committee would have been subordinated to the Board of Education so placing all levels of education under one government department. It was the susceptibilities of the universities that were being protected by placing the UGC under the wing of the Treasury. Since this department of government had no direct interest in education the opportunities for state intervention therefore would be reduced. In 1919-20 the UGC distributed $\& 692,000$ to universities; in 1977-78 the monies to be distributed had reached $£ 597$ million. The magnitude is a partial comment on inflation, but it represents, more accurately, the degree to which British universities have become de- 
pendent on state support. The protective separation of the UGC has been ended. The committee is now under the Department of Education.

5. Armytage, "The Universities of Britain," p.188.

6. G. Woledge and B. S. Page, eds., A Manual of University and College Library Practice (London: Library Association, 1940), p.10.

7. University Grants Committee (UGC), Report of the University Grants Committee (London: H.M.S.O., 1921), p.8.

8. UGC, Returns, 1921-22 (London: H.M.S.O., $1923)$, p.6.

9. UGC, Returns, 1925-26 (London: H.M.S.O., 1927), p.5.

10. UGC, Report, 1928-29 (London: H.M.S.O., 1930), p.38.

11. I have drawn heavily for this section on E. G. Baxter, "A Preliminary Historical Survey of Developments in University Libraries in Great Britain, 1919-1950," Library Association Record 56:330-35 (Sept. 1954) and 56:389-93 (Oct. 1954).

12. Woledge and Page, Manual, p.19.

13. Ibid., p.90.

14. Ibid., p.18.

15. Ibid., p.25.

16. Ibid., p.30.

17. Ibid., p.30.

18. Ibid., p.67.

19. Ibid., p.25.

20. UGC, University Development: Interim Report on the Years 1947 to 1951 (London: H.M.S.O., 1952), p.8.

21. K. W. Humphreys, "The Standing Conference of National and University Libraries," Libri 7:41 (1956).

22. H. J. Heaney, "Standing Conference of National and University Libraries," in British Librarianship and Information Science, 1966-1970 (London: Library Association, 1972), p.676-79.

23. UGC, University Development: Report on the Years 1947 to 1952 (London: H.M.S.O., 1953), p.47-48.

24. UGC, University Development, 1952-57 (London: H.M.S.O., 1958), p.74.

25. Higher Education: Report of the Committee Appointed by the Prime Minister (London: H.M.S.O., 1963).

26. UGC, University Development, 1952-57, p.51.

27. "We approached the Nuffield Foundation in 1956 and asked them if they would undertake an inquiry into the use of university libraries." "In the autumn of 1956 [the Nuffield Foundation] invited the library of the University of Leeds to undertake a pilot survey of the use made of it during the calendar year 1957." UGC, University Development, 1957-1962 (London: H.M.S.O., 1964), p.14. Two surveys were produced as the result of this initiative: B. S. Page and P. E. Tucker, "The Nuffield Pilot Survey of Library Use at the University of Leeds," Journal of Documentation 15:1-11 (March 1959) and P. E. Tucker, "The Sources of Books for Undergraduates," Journal of Documentation 17: 72-95 (June 1961).

28. UGC, University Development, 1957-1962 (London: H.M.S.O., 1964), p.14.

29. "We found little evidence that the problems raised by the Nuffield Foundation surveys or the questions such as those raised above were being considered systematically by the universities or their librarians. Accordingly, we decided, after consultation with the Committee of Vice-Chancellors and Principals, to set up a Committee to advise us on these issues." Ibid., p.15.

30. UGC, Report of the Committee on Libraries (London: H.M.S.O., 1967).

31. M. B. Line, "Information Services in University Libraries" in F. H. Ayres and H. Hall, eds., Information Services in University Libraries (London: SCONUL, 1974), p.3.

32. S. M. Evans and M. B. Line, "A Personalised Service to Academic Researchers: The Experimental Information Service in the Social Sciences at the University of Bath," Journal of Librarianship 5:214-32 (July 1973); J. Martyn, "The OSTI University Information Project," in Ayres and Hall, Information Services in University Libraries, p.46-54.

33. Report of the Committee on Library Resources (London: University of London, 1971).

34. P. C. Peacock, "The Short-Loan Collection in a University Library," Journal of Librarianship 4:130-36 (April 1972).

35. M. K. Buckland, "An Operations Research Study of a Variable Loan and Duplication Policy at the University of Lancaster," $\mathrm{Li}$ brary Quarterly 42:97-106 (Jan. 1972).

36. B. J. Enright, "New Media and the Library," in A. Jeffreys, ed., The Art of the Librarian (Stocksfield: Oriel Press, 1973), p.30.

37. Ibid.

38. "First Report of the General Board's Committee on Libraries," Cambridge University Reporter, March 28, 1969.

39. K. Humphreys, "The Subject Specialist in National and University Libraries," Libri 17:29-41 (1967).

40. W. L. Guttsman, "Subject Specialisation in Academic Libraries: Some Preliminary 
Observations on Role Conflict and Organisational Stress," Journal of Librarianship 5:1-8 (Jan. 1973).

41. University of Leicester. University Library. Annual Report, 1971-1972.

42. R. Sergean et al., The Sheffield Manpower Project: A Survey of Staffing Requirements for Librarianship and Information Work (Sheffield: University of Sheffield, Postgraduate School of Librarianship and Information Science, 1976).

43. W. L. Guttsman, "The Government of University Libraries in Great Britain," Journal of Librarianship 6:203-18 (July 1974).

44. R. O. McKenna, "The Recent Growth of Interest in Management Problems on the Part of British University Libraries," in University Library Problems: Proceedings of a Symposium in Library Science (Uppsala: Uppsala University Library, 1975).

45. G. Ford, "Research in User Behaviour in University Libraries," Journal of Documentation 29:85-106 (March 1973).

46. University of Durham, Project for Evaluating the Benefits from University Libraries: Final Report (Durham: University of Durham, 1969).

47. B. J. Enright and C. R. Taylor, "Stock Control," $R$ \& $D$ Projects in Documentation and Libraries 3, no. 5 (1973). J. A. Urquhart and N. C. Urquhart, Relegation and Stock Control in Libraries (Stocksfield: Oriel Press, 1976).

48. A. G. McKenzie et al., "Acquisition, Stockholding and Discarding Policy in Academic Libraries," $R$ \& $D$ Projects in Documentation and Libraries 5, no. 2 (1975).

49. M. K. Buckland, et al., Systems Analysis of a University Library (Lancaster: University of Lancaster, 1970).

50. J. C. Gray, "The British Library Research and Development Department," in W. L. Saunders, ed., British Librarianship Today (London: Library Association, 1977), p.136-48.

51. This project was established following the publication of T. D. Wilson and W. A. J.
Masterson, Local Library Cooperation (Sheffield: University of Sheffield, 1974).

52. I owe this particular point to Professor W. L. Saunders.

53. H. Bryan, University Libraries in Britain (London: Bingley, 1976), p.59.

54. H. F. Brown, ed. Planning the Academic Library: Metcalf and Ellsworth at York (Stocksfield: Oriel Press, 1971).

55. H. Bryan, University Libraries in Britain, p.68.

56. J. D. Reynolds, ed. Library Buildings, 1965 (London: Library Association, 1966), p.89.

57. N. Higham, Computer Needs for University Library Operations (London: SCONUL, 1973), p.28.

58. A. Vickery, "Conference on the Future Role of Computer Information Services at the University of London," University of London, Libraries Bulletin, no. 9 (Jan.March 1977), p.19.

59. Vine: A Very Informal Newsletter on Library Automation, issued by The Library, University of Southampton.

60. J. Thompson, "University Libraries," in H. A. Whatley, ed. British Librarianship and Information Science, 1966-1970 (London: Library Association, 1972), p.365.

61. N. Roberts and G. Bull, "Some Implications of the Trend in External Borrowing by University Libraries, 1960/61-1972/73," Journal of Librarianship 8:153-65 (July 1976).

62. For example, SCONUL, Aspects of Library Services in a Period of Financial Constraint (London: SCONUL, 1975); SCONUL, Information Services Group, "Conference on the Future of Information Services in the Period of Financial Restraint," July 1977.

63. UGC, Capital Provision for University Libraries: Report of a Working Party (London: UGC, 1976), foreword, p.2. The "Atkinson Report."

64. For a full and balanced appraisal of the Atkinson Report see the review by W. L. Saunders in Journal of Documentation 33: 160-64 (June 1977). 